\title{
ZNAMO LI KOLIKO VRIJEDE NAŠI FONDOVI? USKLAĐIVANJE FINANCIJSKE VRIJEDNOSTI KNJIŽNIČNOG FONDA S RAČUNOVODSTVENIM STANJEM U KNJIŽNICAMA GRADA ZAGREBA
}

\author{
HOW MUCH ARE OUR MATERIALS WORTH? \\ HARMONIZING THE FINANCIAL VALUE OF LIBRARY \\ MATERIALS WITH ACCOUNTING RECORDS \\ IN ZAGREB CITY LIBRARIES
}

\begin{abstract}
Maja Bodiš
Knjižnice grada Zagreba

maja.bodis@kgz.hr

Jasmina Kenda

Knjižnice grada Zagreba

jasmina.kenda@kgz.hr

Petra Kožul

Knjižnice grada Zagreba

petra.kozul@kgz.hr
\end{abstract}

UDK / UDC 021.9:025.11(497.5 Zagreb)

Stručni rad / Professional paper

Primljeno / Received: 26. 3. 2020.

Prihvaćeno / Accepted: 5. 6. 2020.

\section{Sažetak}

Cilj. Rad otvara raspravu o pitanjima financijske vrijednosti knjižničnih fondova, zakonske legislative koju je potrebno poštivati, ekonomske pismenosti knjižničara te o važnosti suradnje knjižničara i računovodstvenih službi s ciljem kvalitetno uređenog poslovanja.

Vjesnik bibliotekara Hrvatske 63, 1-2(2020), 411-423 ISSN 0507-1925 
Pristup. Tijekom 2016. godine donesena je odluka o potrebi financijskog usklađivanja poslovanja u mreži Knjižnica grada Zagreba. Do potrebe financijskog usklađivanja došlo je zbog informatizacije knjižničnog poslovanja koje se prebacilo iz analognog u digitalno te zbog promjene nekoliko različitih knjižničnih softvera. Proces financijskog usklađivanja poslovanja proveden je tijekom 2017. i 2018. godine na 40 lokacija i u Bibliobusnoj službi. Rad se temelji na primjeru dobre prakse financijskog usklađivanja poslovanja te svoj popratnoj dokumentaciji koja je izrađena za potrebe istog. Sve to napravljeno je da bi se postigao krajnji cilj - usklađivanje knjižničnog fonda iz pisanih inventarnih knjiga s elektroničkom inventarnom knjigom i popisom imovine te knjigovodstvenim stanjem u Službi financija i računovodstva.

Rezultati. Nakon uspješno provedenog procesa usklađivanja, stvarna financijska vrijednost knjižnične građe u knjižnici odgovara knjigovodstvenom stanju u računovodstvenim evidencijama. Takav rezultat ističe važnost usklađenosti financijske vrijednosti knjižničnog fonda u inventarnim knjigama s knjigovodstvenim evidencijama.

Originalnost/vrijednost. Ovaj rad doprinosi jasnijem definiranju kvalitetne suradnje knjižničara i računovodstvenih službi koja se nameće kao nužnost u zakonski utemeljenom knjižničnom poslovanju.

Ključne riječi: financijska vrijednost fonda, inventarna knjiga, računovodstvena evidencija

\section{Abstract}

Purpose. The paper opens a discussion on the questions of the assessment of library holdings' financial value, the legislative guidance that is crucial in this process, the economic literacy of librarians and the collaborative efforts between librarians and accounting departments' teams in order to achieve the efficient functioning of a library.

Approach. In 2016, a decision was made that the financial harmonization of library operations in the Zagreb City Libraries was necessary. The need for the financial harmonization arose due to the computerization of library operations, which had switched from analog to digital, and several different library software packages have been changed in the past few years. The process of the financial harmonization of operations was carried out during 2017 and 2018 in 40 libraries and mobile library service. This paper is based on the example of good practice of financial harmonization of library operations and the supporting documentation prepared for this process. All this was done in order to achieve the ultimate goal - the harmonization of the handwritten paper inventory books of library materials with the electronically maintained records of the inventory, as well as the inventory lists of property items and the accounting records in the Office of financial and accounting services.

Findings. After the successful process of harmonization, the actual financial value of the library materials in the library corresponds to the book balance in the accounting 
records. This result highlights the importance of reconciling the financial value of the library holdings in the inventory books with the accounting records.

Originality/value. This paper contributes to a clearer definition of quality cooperation between librarians and accounting services, which is imposed as a necessity in the legally established library business.

Keywords: inventory books, financial value of library holdings, accounting records

\section{Uvod}

Na temelju Zakona o proračunu (NN 87/08, 136/12 i 15/15) ${ }^{1}$ i Pravilnika o proračunskom računovodstvu i računskom planu (NN 124/14, 115/15, 87/16 i 3/18 i $126 / 19)^{2}$ knjižnice su dužne voditi popis imovine knjižnične građe te imati usklađene financijske podatke u pomoćnim financijskim knjigama koje vode knjižničari s računovodstvenim stanjem u temeljnim financijskim knjigama koje vode računovodstvene službe.

Računovodstveni propisi kojih su se knjižnice kao korisnici proračunskih sredstava dužne pridržavati jasno navode potrebu usklađivanja financijske vrijednosti knjižničnog fonda u pomoćnim financijskim knjigama koje vode knjižničari (inventarne knjige) s temeljnim financijskim knjigama koje vodi računovodstvena služba (glavna knjiga).

Knjižnice redovno vode inventarne knjige u kojima se za svaku jedinicu građe izražava njezina vrijednost (nabavna vrijednost za kupljenu građu i procijenjena vrijednost za darove i zamjenu) te periodički obavljaju revizije i otpise temeljem Zakona o knjižnicama (NN 105/97, 5/98, 104/00, 69/09) ${ }^{3}$ i Pravilnika o reviziji i otpisu knjižnične građe (NN 21/02) ${ }^{4}$. Tijekom godine vrijednost fonda knjižnice uvećava se za prinovljenu građu tekuće godine te umanjuje za vrijednost otpisane građe iste godine.

Uvriježeno je mišljenje knjižničara da su financijsko poslovanje i računovodstvene evidencije izvan njihovog opsega posla te knjižničari koji rade u odjelima

\footnotetext{
1 Zakon o proračunu. // Narodne novine 87, 2791(2008). [citirano: 2020-02-28]. Dostupno na: https://narodne-novine.nn.hr/clanci/sluzbeni/2008_07_87_2791.html

2 Pravilnik o proračunskom računovodstvu i računskom planu. // Narodne novine 124, 2374(2014). [citirano: 2020-02-28]. Dostupno na: https://narodne-novine.nn.hr/clanci/sluzbeni/2014_10_124_2374.html

3 Zakon o knjižnicama i knjižničnoj djelatnosti. // Narodne novine 17, 356(2019). [citirano: 202002-28]. Dostupno na: https://narodne-novine.nn.hr/clanci/sluzbeni/full/2019 02 17 $356 . h$ tml

4 Pravilnik o reviziji i otpisu knjižnične građe. // Narodne novine 21, 503(2002). [citirano: 202002-28]. Dostupno na: https://narodne-novine.nn.hr/clanci/sluzbeni/2002_03_21_503.html
} 
nabave knjižnične građe često ne posjeduju teorijska i praktična ekonomska znanja koja su nužna za ispravan rad.

Knjižničari se često služe terminom „kulturno dobro“ opisujući na taj način svoje knjižnice i zbirke zaboravljajući da svako „kulturno dobro“ ima i svoju točnu financijsku vrijednost koju je potrebno opisati i uskladiti s računovodstvenim evidencijama u smislu izražavanja vrijednosti fonda.

Knjižnice grada Zagreba suvremena su mreža knjižnica koja objedinjuje Gradsku knjižnicu i Knjižnicu Božidara Adžije kao centralne knjižnice mreže, Bibliobusnu službu te još dvanaest područnih knjižnica s njihovim ograncima na ukupno 42 lokacije u Gradu Zagrebu. Model nabave u Knjižnicama grada Zagreba koordinirana je nabava građe koja obuhvaća 15 odjela nabave u područnim knjižnicama s voditeljima nabave koji samostalno raspolažu sredstvima za nabavu građe i izgrađuju zbirke svojih knjižnica. Svaki odjel nabave samostalno vodi inventarne knjige, pri čemu su do 1999. godine vođene isključivo pisane inventarne knjige, a od siječnja 1999. godine građa se unosi u elektroničku inventarnu knjigu.

Zbog potrebe da se knjižnično poslovanje uskladi s računovodstvenim stanjem, a uslijed informatizacije knjižničnog poslovanja koje se prebacilo iz analognog u digitalno te nekoliko promjena knjižničnih softvera, Knjižnice grada Zagreba pristupile su financijskom usklađivanju poslovanja. Dodatno potaknuti uvjetnim nalazom Državne revizije (2013.) koji je tražio potpunu financijsku usklađenost knjižničnog i računovodstvenog stanja,${ }^{5}$ krenulo se u dugotrajan proces rješavanja tog pitanja.

Cilj je ovog rada osvijestiti potrebu poznavanja i praćenja računovodstvenih propisa i zakona kojima podliježe knjižnično poslovanje čime se, uz neophodnu suradnju knjižničara i računovodstvenog osoblja, postiže zakonski utemeljeno funkcioniranje knjižničnih ustanova.

\section{Teorijske pretpostavke}

Početnim pretraživanjem zakona i propisa koji se odnose isključivo na knjižničnu djelatnost nije pronađena potvrda potrebe usklađenosti knjižničnog i računovodstvenog stanja.

Zakon o knjižnicama i knjižničnoj djelatnosti (NN 17/19, 98/19) $)^{6}$ ne spominje izrijekom financijsku vrijednost fonda, iako u članku 33. govori o knjižničnom sustavu Republike Hrvatske te propisuje standardizaciju i usklađivanje postupaka u nabavi i izgradnji knjižničnih zbirki.

\footnotetext{
5 Izvješće o obavljenoj reviziji: Knjižnice grada Zagreba. Zagreb: Državni zavod za reviziju, 2015. [citirano: 2020-02-06]. Dostupno na: http://www.revizija.hr/izvjesca/2015/revizija/pojedinacna_izvjesca/knjiznice/knjiznice_grada_zagreba.pdf

6 Zakon o knjižnicama i knjižničnoj djelatnosti. // Narodne novine 17, 356(2019). [citirano: 202002-28]. Dostupno na: https://narodne-novine.nn.hr/clanci/sluzbeni/full/2019_02_17_356.html
} 
Pravilnik o reviziji i otpisu knjižnične građe (NN 21/02) navodi potrebu periodičkog provođenja revizije i otpisa te utvrđivanja stvarnog stanja knjižnične građe i njezine materijalne vrijednosti, ali ne spominje umanjivanje vrijednosti fonda protekom vremena (amortizaciju) kao ni potrebu izrade popisa imovine.

Standardi za narodne knjižnice u Republici Hrvatskoj (NN 58/99) ${ }^{8}$ ne spominju ni u kojem kontekstu financijsku vrijednost knjižničnog fonda.

Iako se računovodstvo, prije svega zaduženo za vrijednosno (ekonomsko) praćenje knjižnične građe i poslovanje, nigdje izravno ne spominje u nizovima zakona u sklopu kojih djeluju knjižnice, Pravilnik o proračunskom računovodstvu i računskom planu (NN 124/14, čl. 25. st. 4.) $)^{9}$ jasno definira knjige (u papirnatom obliku ili na elektronskim medijima) kao proizvedenu dugotrajnu imovinu unutar općeg proračuna koja se evidentira u podskupini računa 024.

Prema Pravilniku razlikuju se knjige koje knjižnice i slične ustanove unutar općeg proračuna posjeduju i izlažu (posuđuju) od knjiga koje se čuvaju pohranjene i ne koriste u procesu pružanja usluga, a koje se evidentiraju u skupini računa 03 računskog plana proračunskog računovodstva.

Pravilnik u članku 14. propisuje da proračun i proračunski korisnici koji obavljaju knjižničnu djelatnost popis knjižnične građe mogu obaviti u roku koji nije duži od roka za provođenje obvezne redovne revizije knjižnične građe utvrđene posebnim podzakonskim aktom, pri čemu se misli na Pravilnik o reviziji i otpisu knjižnične građe, ${ }^{10}$ čime je uzet u obzir obim knjižnične građe kao kriterij provođenja revizije te popisa i specifičnost poslovanja knjižnica.

Stručna literatura koja se bavi financijskom vrijednošću fonda malobrojna je, kako domaća tako i svjetska.

Tadić govori o procjeni vrijednosti fonda isključivo u smislu sadržajne evaluacije (načelo vrijednosti, odnosno kakvoće fonda), ali ne i financijske vrijednosti. ${ }^{11}$

IFLA-ini Darovi za zbirke ${ }^{12}$ vrlo detaljno opisuju postupak odluke o (ne)uvrštavanju darovane građe u fond knjižnice, ali uopće ne govore išta o procjeni fi-

\footnotetext{
Pravilnik o reviziji i otpisu knjižnične građe. // Narodne novine 21, 503(2002). [citirano: 202002-28].Dostupno na: https://narodne-novine.nn.hr/clanci/sluzbeni/2002_03_21_503.html

8 Standardi za narodne knjižnice u Republici Hrvatskoj. // Narodne novine 58, 1071(1999). [citirano: 2020-02-28]. Dostupno na: https://narodne-novine.nn.hr/clanci/sluzbeni/1999_06_58_1071.html

9 Pravilnik o proračunskom računovodstvu i računskom planu. // Narodne novine 124, 2374(2014). [citirano: 2020-02-28]. Dostupno na: https://narodne-novine.nn.hr/clanci/sluzbeni/2014_10_124_2374.html

10 Pravilnik o reviziji. Nav. dj.

11 Tadić, K. Rad u knjižnici. Opatija: Naklada Benja, 1994. Str. 33-41.

12 Darovi za zbirke: smjernice za knjižnice. Upute za izradbu smjernica za izgradnju knjižnične zbirke primjenom modela Conspectus. Međunarodna posudba i dostava dokumenata: načela i smjernice za postupanje. Model nacionalnog pravilnika za međuknjižničnu posudbu / [glavna urednica Ana Barbarić]. Zagreb: Hrvatsko knjižničarsko društvo, 2010. Str. 19-23.
} 
nancijske vrijednosti građe niti o evidencijama o uvrštavanju darovane građe u fond, koje je potrebno proslijediti i u računovodstvo.

IFLA-ine smjernice za narodne knjižnice ${ }^{13} u$ poglavlju koje govori o pravnim i financijskim okvirima spominju financiranje kojim se omogućuje rad na razini ustanove te navode izvore financiranja (porezi na lokalnoj i regionalnoj razini, namjenska sredstva iz proračuna, donacije raznih financijera, tijela ili pojedinaca, prihod od komercijalnih aktivnosti knjižnice, prihod od korisnika i naplaćivanja dodatnih knjižničnih usluga kao i različita sponzorstva), ali također ne spominje financijsku vrijednost građe. Ni u dijelu koji navodi postupke vezane za izgradnju zbirke nema osvrta na financijsku vrijednost građe. Zanimljivo je napomenuti da smjernice navode vještine ${ }^{14}$ koje se očekuju od knjižničnog osoblja kako bi knjižnica dobro funkcionirala, od tradicionalnih koje se odnose na knjižničnu praksu i različitih organizacijskih vještina do novijih vezanih za tehnologiju, korisničke usluge i međuljudske odnose. Ponovo nema niti spomena o financijskim vještinama koje su, barem knjižničarima u hrvatskom knjižničnom prostoru, neosporno potrebne kako bi zadovoljili zahtjeve svog posla. Pretpostavka je da je proces izgradnje zbirki i njezinih evidencija različit u različitim dijelovima svijeta, kao što su svakako različiti i lokalni zakoni i propisi (knjižnični, ali i računovodstveni), pa se zbog toga u općenitim smjernicama niti ne spominje financijska vrijednost građe i računovodstvene evidencije. Javno dostupni nalazi provedenih državnih revizija ${ }^{15} \mathrm{u}$ različitim knjižnicama u Republici Hrvatskoj potvrđuju svakako pretpostavku da je knjižničarima potrebno dodatno financijsko obrazovanje jer su se upravo glavne zamjerke provedenog nadzora odnosile na neusklađenost knjižničnih i računovodstvenih evidencija.

Johnson ${ }^{16}$ navodi kako se većina knjižnica oslanja na računovodstvene službe prilikom evidentiranja financijskih transakcija koje knjižnica poduzima, no knjižničari koji su odgovorni za izgradnju zbirki moraju potpuno razumjeti računovodstvene propise, zakone i mogućnosti, ali i ograničenja koja iz njih proizlaze.

Rezultat pretraživanja mrežnog kataloga Knjižnica grada Zagreba s upitom predmetnica knjižnice-računovodstvo samo je jedna jedinica građe - Kakve veze ima knjižnica s računovodstvom? ${ }^{17}$ Knjiga može poslužiti kao priručnik knjižničarima koji imaju nedoumica vezanih za financijsko poslovanje knjižnice. Iako

\footnotetext{
13 IFLA-ine smjernice za narodne knjižnice / uredile Christie Koontz i Barbara Gubbin. Zagreb: Hrvatsko knjižničarsko društvo, 2011. Str. 31-40.

14 Isto, str. 79.

15 Pretraživanjem interneta pronađeni su javno dostupni nalazi državnih revizija pojedinih knjižnica u Republici Hrvatskoj te su analizirani podaci navedeni u tim izvještajima. (06. veljače 2020.)

16 Johnson, P. Fundamentals of collection development and management. Chicago: American Library Association, 2009. Str. 107.

17 Kretić Nađ, M.; M. Vehabović Štrak; R. Benić. Kakve veze ima knjižnica s računovodstvom? Beli Manastir: Gradska knjižnica, 2018. Str. 76-78.
} 
sadržaj knjige obuhvaća cjelokupno financijsko poslovanje knjižnice, u ovom radu osvrnut ćemo se na dio koji se odnosi na iskazivanje financijske vrijednosti fonda. Kretić-Nađ, Vehabović Štrak i Benić u računovodstvenom smislu definiraju kupovinu knjižnične građe kao kapitalna ulaganja (rashode za nabavu nefinancijske imovine), a inventarne knjige kao računovodstvene isprave te navode da se inventarne knjige dugotrajne i kratkotrajne nefinancijske imovine vode u računovodstvu, a inventarne knjige kao pomoćne knjige analitičke računovodstvene evidencije vode knjižničari. ${ }^{18}$ To je u skladu s propisima Pravilnika o proračunskom računovodstvu i računskom planu kojeg su se knjižnice kao proračunski korisnici dužne pridržavati. Autorice ističu važnost računovodstvenog uvećavanja vrijednosti ukupne imovine prinovljene darom, otkupom, zamjenom ili obveznim primjerkom (u računovodstvenom smislu svi navedeni načini nabave tretiraju se kao dar) kao i računovodstvenog umanjivanja vrijednosti ukupne imovine nakon provedenog godišnjeg redovitog otpisa ili otpisa nakon revizije građe. Popis imovine i obveza u smislu popisa knjižnične građe obavlja se periodički s obzirom na veličinu knjižničnog fonda, a sukladno odredbama Pravilnika o reviziji i otpisu knjižnične građe, $i$ to je iznimka od Pravilnika o proračunskom računovodstvu i računskom planu, koji propisuje godišnje obavljanje popisa imovine i obveza. Autorice govore i o obavezi usporedbe računovodstvene vrijednosti knjižničnog fonda s knjigom inventara na kraju svake proračunske godine, čime se potvrđuje i zaključuje godišnji izračun vrijednosti knjižničnog fonda.

Dostupni nalazi državne revizije knjižničnih ustanova govore o tome da je osnovna svrha godišnjeg popisa imovine usklađivanje računovodstvenog stanja sa stvarnim stanjem, ${ }^{19}$ a pritom vrlo često vrijednost knjižničnog fonda evidentirana u poslovnim knjigama i iskazana u financijskim izvještajima nije usklađena $s$ knjigama inventara. ${ }^{20} \mathrm{U}$ Pravilniku o proračunskom računovodstvu i Računskom planu (članak 14.) propisano je da proračunski korisnici moraju popisati imovinu i obveze te navesti njihove pojedinačne vrijednosti u naturalnim i novčanim izrazima. ${ }^{21}$ Ta neusklađenost proizlazi iz toga što u nekim knjižnicama za većinu nabavljene knjižnične građe nisu unesene jedinične cijene u knjižnične računalne programe, odnosno nije utvrđeno stvarno stanje knjižnične građe. ${ }^{22}$ Ako knjižnica

\footnotetext{
18 Isto, str. 52-54.

19 Izvješće o obavljenoj reviziji: Gradska knjižnica i čitaonica Metel Ožegović. Varaždin: Državni zavod za reviziju, 2015. [citirano: 2020-02-06]. Dostupno na: http://www.revizija.hr/izvjesca/2015/revizija/pojedinacna_izvjesca/knjiznice/gradska_knjiznica_i_citaonica_metel_ozegovic_varazdin.pdf

20 Izvješće o obavljenoj reviziji: Gradska knjižnica Krapina. Krapina: Državni zavod za reviziju, 2015. [citirano: 2020-02-06]. Dostupno na: http://www.revizija.hr/izvjesca/2015/revizija/pojedinacna_izvjesca/knjiznice/gradska_knjiznica_krapina.pdf

21 Pravilnik o proračunskom računovodstvu. Nav. dj.

22 Izvješće o obavljenoj reviziji: Nacionalna i sveučilišna knjižnica u Zagrebu. Zagreb: Državni zavod za reviziju, 2015. [citirano: 2020-02-06]. Dostupno na: http://www.revizija.hr/izvjesca/2015/
} 
do sada nije izrađivala popise, Državni ured za reviziju nalaže obavljanje popisa cjelokupne imovine u skladu s odredbama Pravilnika o proračunskom računovodstvu i Računskom planu. ${ }^{23}$

Telenta ${ }^{24}$ kao temelj provođenja revizije knjižnične građe navodi inventarne knjige koje definira kao analitičku evidenciju dugotrajne imovine. Otpis knjižnične građe na temelju provedene revizije potrebno je evidentirati u inventarnim knjigama, ali i u računovodstvenim evidencijama. Nakon završetka revizije i izvršenih promjena u svim evidencijama, stvarno stanje knjižnične građe na policama treba odgovarati računovodstvenom stanju. Knjižnica iskazuje točan popis imovine nakon provedene revizije.

\section{Proces usklađivanja financijske vrijednosti fonda u Knjižnicama grada Zagreba}

Pregledom poslovanja u Knjižnicama grada Zagreba tijekom 2016. godine utvrđeno je da pojedine knjižnice nemaju usklađene pisane inventarne knjige knjižnične građe s elektroničkim inventarnim knjigama knjižnične građe u knjižničnom programu ZaKi (pomoćna knjiga). Većina građe (97 \%) nalazila se evidentirana u elektroničkim inventarnim knjigama, ali dijelu fonda (otprilike $5 \%{ }^{25}$ ) nedostajala je upisana financijska vrijednost pojedinačnih stavki.

Stanje u inventarnim knjigama razlikovalo se od stanja u računovodstvenim evidencijama (glavna knjiga) Knjižnica grada Zagreba, te je bilo je potrebno izvršiti usklađivanje financijske vrijednosti knjižničnog fonda. Preduvjet za provođenje tog financijskog usklađivanja bila je provedena revizija cjelokupnog fonda knjižnice i kroz knjižnični program ZaKi kako bi se izvršila provjera je li sav postojeći fond knjižnice unesen $u$ isti.

Nakon što je uprava knjižnice donijela odluku o provođenju tog procesa, osnovan je radni tim koji je educirao sve djelatnike u njihovim knjižnicama o procesu rada, bio stručna podrška kolegama u čitavom procesu te kontrolirao napravljeno.

Prva je zadaća bila utvrditi stvarno stanje u svakoj pojedinoj knjižnici, popisati sve potrebne radnje te izraditi radne upute ${ }^{26}$ jer je u procesu sudjelovalo više knjižničara (30-ak djelatnika u mreži Knjižnica grada Zagreba). Zbog velike količine građe koju u svom fondu imaju knjižnice u mreži Knjižnica grada Zagreba

\footnotetext{
revizija/pojedinacna_izvjesca/knjiznice/nacionalna_i_sveucilisna_knjiznica_u_zagrebu.pdf

${ }^{23}$ Izvješće o obavljenoj reviziji: Knjižnice grada Zagreba. Nav. dj.

24 Telenta, V. Specifičnosti knjigovodstvenog evidentiranja i popisa knjižnične građe. // Računovodstvo, revizija i financije 25, 2(2015), str. 19.

25 Procjena projektnog tima

26 Upute za usklađivanje inventarnih knjiga [interni dokument]
} 
(2 380991 jedinica građe ${ }^{27}$ ), ali i redovnih obaveza djelatnika, očekivano trajanje provođenja tog procesa bilo je godina dana. $\mathrm{U}$ tom razdoblju, u praksi se pokazalo da su potrebna u prosjeku tri odlaska na teren kako bi se proces proveo. Prilikom prvog odlaska utvrdilo se zatečeno stanje u pojedinoj knjižnici, a knjižničari koji su određeni za provođenje procesa usklađivanja prošli su obuku potrebnu za rad. Drugi odlazak podrazumijevao je kontrolu procesa rada i eventualno rješavanje problema, dok je treći odlazak bio završna provjera nakon provedenog procesa.

Usklađivanje financijske vrijednosti fonda započelo je usporedbom stavki u pisanim inventarnim knjigama s onima u elektroničkoj inventarnoj knjizi, posebno obraćajući pozornost na cijenu pojedinog dokumenta. Ako dokument u elektroničkoj inventarnoj knjizi nije imao naznačenu cijenu, ona se prepisivala iz pisane inventarne knjige (ako se radilo o građi inventariziranoj nakon 1. 6. 1994.) ili se procjenjivala vrijednost građe u slučaju da ta informacija nije bila poznata. Bilo je potrebno uskladiti sve pisane inventarne knjige koje knjižnica posjeduje. Pisana inventarna knjiga smatrala se usklađenom kada se u polju napomene svih jedinica građe nalazi ili informacija o otpisu jedinice građe ili informacija da je građa zavedena u elektroničku inventarnu knjigu te kada su vrijednosti (nabavna ili procijenjena) pojedinih dokumenata unesene u elektroničku inventarnu knjigu.

Tijekom procesa rada utvrđeno je da je potrebno kontinuirano praćenje i podrška radu kolegicama na njihovim lokacijama kako bi se sustavno mogla održavati kvaliteta stručnog rada i kako bi nabava knjižnične građe bila koordinirana i usklađena u svim knjižnicama mreže Knjižnica grada Zagreba.

Usklađivanje je započelo u ožujku 2017. godine, a završeno je u prosincu 2018. godine, te se financijska vrijednost ukupnog aktivnog fonda evidentirana u knjižničnom programu ZaKi 31. 12. 2018. smatrala temeljem za usklađivanje s računovodstvenim stanjem u Službi financija i računovodstva Knjižnica grada Zagreba (glavna poslovna knjiga).

\section{Iskazivanje vrijednosti fonda}

Na prijedlog radnog tima uprava knjižnice donijela je Odluku o izražavanju financijske vrijednosti knjižničnog fonda ${ }^{28}$ Zbog ujednačavanja financijske vrijednosti knjižničnog fonda čitave mreže, odlučeno je da se vrijednost knjižnične građe inventarizirane do 31. 5. 1994. u elektroničkim inventarnim knjigama izrazi kao financijska vrijednost $0,00 \mathrm{kn}$.

Odluka se temeljila na strukturi fondova knjižnica iz mreže Knjižnica grada Zagreba. Naime, radi se o knjižnicama osnovanima prije 70-ak godina, koje su

27 Izvještaj o radu 2018. Zagreb: Knjižnice grada Zagreba, 2019.

28 Odluka o izražavanju financijske vrijednosti knjižničnog fonda KGZ-a od 28. 3. 2017. [interni dokument] 
tada funkcionirale kao samostalne ustanove te su inventarne knjige vođene na različite načine. Prilikom integracije tih knjižnica u mrežu Knjižnica grada Zagreba nije obavljeno usklađivanje financijske vrijednosti fondova tih knjižnica s računovodstvenim evidencijama.

Dodatna poteškoća bila je i promjena valute kojom je građa kupovana i evidentirana u pisanim inventarnim knjigama. Uslijed državnih promjena kroz navedenih 70-ak godina valute u kojima je građa nabavljana bile su redom: kuna, jugoslavenski dinar, hrvatski dinar i hrvatska kuna. U preračunavanju (denominacija) u današnju valutu, vrijednost pojedine jedinice građe svedena je na $0,00 \mathrm{kn}$. Za svu građu nabavljenu nakon 1. 6. 1994., od kada Republika Hrvatska uvodi valutu hrvatsku kunu, u elektroničkim inventarnim knjigama iskazana je nabavljena vrijednost (za kupljenu građu) ili procijenjena vrijednost (za darovanu građu) u hrvatskim kunama.

Iznimka su toj odluci specijalne zbirke (npr. zavičajna zbirka, zbirke stare i rijetke knjige, grafička zbirka i sl.) te se vrijednost svake pojedine jedinice građe u tim zbirkama mora posebno procijeniti.

Telenta navodi da su knjige u knjižnicama predmeti proizvedene dugotrajne imovine te se njihova vrijednost iskazuje prema trošku nabave (nabavnoj vrijednosti), odnosno procijenjenoj vrijednosti za darove. Nabavnu vrijednost knjige čini kupovna cijena uvećana za carine, nepovratne poreze, troškove prijevoza i sve druge troškove koji se mogu izravno dodati troškovima nabave. Kupovna je cijena ona koju treba platiti po računu dobavljača, a može sadržavati rabate, popuste koji su iskazani na računu te smanjuju nabavnu cijenu. To je bitno jer knjižničar pri evidentiranju vrijednosti knjige u pomoćnoj evidenciji, odnosno inventarnoj knjizi, unosi nabavnu cijenu knjige, nakon svih obračunatih popusta, rabata te možebitnog uvećanja nabavne cijene zbog troškova poštarine, carine itd. ${ }^{29}$ Stoga je troškove koji se povezuju s nabavom knjiga, a na računu su iskazani u ukupnoj svoti, potrebno alikvotno podijeliti prema vrijednosti predmeta na koji se odnose, kako bismo dobili njegovu nabavnu vrijednost.

Ukupna vrijednost kupljene knjižnične građe koja je evidentirana u inventarnoj knjizi tijekom godine treba odgovarati ukupno nabavljenoj građi evidentiranoj u računovodstvu, na temelju računa dobavljača.

Osim kupnje, knjige mogu biti nabavljene putem dara, obveznog primjerka, zamjenom, odnosno otkupom i u tim slučajevima primjenjuju se posebne računovodstvene evidencije.

Za prijenose građe unutar proračuna (između proračunskog korisnika državnog proračuna i proračunskog korisnika JLP(R)S) evidentiranje knjižnične građe obavlja se putem računa promjene u obujmu imovine, kako nalaže čl. 55. st. 5.

29 Telenta, V. Nav. dj., str. 19. 
Pravilnika o proračunskom računovodstvu i računskom planu, ${ }^{30}$ a postupanje $\mathrm{s}$ dobivenim donacijama koje stižu izvan općeg proračuna propisuje čl. 55. st. 3. Pravilnika.

Prema tome, bilo da se knjižnična građa nabavlja kupnjom, darom, otkupom, zamjenom ili drugačije, vrijednost ukupne dugotrajne imovine u analitičkoj evidenciji (inventarnoj knjizi) treba odgovarati ukupnoj dugotrajnoj imovini podskupine 0241 knjige u glavnoj knjizi.

O ispravku vrijednosti knjiga tumačenja su neujednačena, pa tako Telenta ${ }^{31}$ tvrdi da prema čl. 19. Pravilnika o proračunskom računovodstvu i računskom planu, vrijednost dugotrajne imovine ispravlja se po prosječnim godišnjim stopama linearnom metodom, ali se vrijednost knjiga i ostalih pohranjenih vrijednosti (podskupina 024) u pravilu ne ispravlja. Najviše zbog toga što knjige zbog svoje specifičnosti namjene, protekom vremena ne gube na uporabnoj i funkcionalnoj vrijednosti. S obzirom na to da je Pravilnik propisao stopu ispravka vrijednosti knjiga koja iznosi $20 \%$, knjižnice koje obavljaju ispravak vrijednosti knjiga ne čine pogrešku.

\section{Završetak procesa}

Zadnji korak i cilj procesa bilo je usklađivanje financijske vrijednosti knjižničnog fonda u temeljnim računovodstvenim knjigama s financijskom vrijednosti knjižničnog fonda u pomoćnim računovodstvenim knjigama (inventarnim knjigama).

Nakon završetka usklađivanja Upravno vijeće knjižnice donijelo je Odluku o isknjiženju dugotrajne i kratkotrajne nefinancijske imovine iz knjigovodstvene evidencije ${ }^{32} \mathrm{u}$ kojoj se nalaže Službi računovodstva i financija da izvrši potrebna knjiženja radi usklađivanja financijske vrijednosti knjižničnog fonda iz elektroničke inventarne knjige u knjižničnom programu ZaKi s računovodstvenim stanjem 31 . 12. 2018. Nakon provedenih knjiženja stvarna financijska vrijednost knjižnične građe u knjižnici odgovara stanju u računovodstvenim evidencijama.

Kako bi financijska vrijednost fonda u objema navedenim evidencijama (inventarnoj knjizi i računovodstvenoj evidenciji) ostala usklađena, važno je da u budućem poslovanju knjižničari svaku promjenu vezanu za vrijednost fonda koju evidentiraju u inventarnim knjigama dostave u računovodstvo. Nakon završetka kalendarske godine i podnošenja financijskih izvještaja, onemogućeno je unošenje financijskih promjena za zaključena stanja.

\footnotetext{
30 Pravilnik o proračunskom. Nav. dj.

31 Telenta, V. Nav. dj., str. 21.

32 Odluka o isknjiženju dugotrajne i kratkotrajne nefinancijske imovine iz knjigovodstvene evidencije od 23. 1. 2018. [interni dokument]
} 
Završetkom navedenog procesa u Knjižnicama grada Zagreba ${ }^{33}$ pisane inventarne knjige postale su arhivsko gradivo koje se trajno čuva, ali se u njih promjene više ne unose. Elektroničke inventarne knjige time postaju jedini važeći knjižnični izvor informacija.

\section{Zaključak}

Svrha ovog rada bila je prikazati model koji su Knjižnice grada Zagreba primijenile prilikom usklađivanja knjižničnog fonda iz pisanih inventarnih knjiga s elektroničkom inventarnom knjigom i popisom imovine te računovodstvenim stanjem u Službi financija i računovodstva.

Osvjetljavanje pitanja financijske vrijednosti knjižničnih fondova, poznavanja zakonske legislative, potrebe ekonomske pismenosti knjižničara te nužne suradnje knjižničara i računovodstvenih službi nameće se kao nužnost u zakonski utemeljenom knjižničnom poslovanju.

Sveučilišni programi obrazovanja knjižničara u Republici Hrvatskoj nemaju u svojim programima edukaciju vezanu za financijsko i računovodstveno poslovanje knjižnice, što je i razumljivo jer se takvi studijski programi nalaze u društveno-humanističkom znanstvenom polju informacijskih i komunikacijskih znanosti, a ne u znanstvenom polju ekonomskih znanosti. Budući da praksa pokazuje da takva znanja ipak nedostaju knjižničarima, potrebno je razmisliti o dodatnim edukacijama iz tog područja.

\section{LITERATURA}

Darovi za zbirke: smjernice za knjižnice. Upute za izradbu smjernica za izgradnju knjižnične zbirke primjenom modela Conspectus. Međunarodna posudba i dostava dokumenata: načela i smjernice za postupanje. Model nacionalnog pravilnika za međuknjižničnu posudbu / [glavna urednica Ana Barbarić]. Zagreb: Hrvatsko knjižničarsko društvo, 2010.

IFLA-ine smjernice za narodne knjižnice / uredile Christie Koontz i Barbara Gubbin. Zagreb: Hrvatsko knjižničarsko društvo, 2011.

Izvješće o obavljenoj reviziji: Gradska knjižnica i čitaonica Metel Ožegović. Varaždin: Državni zavod za reviziju, 2015. [citirano: 2020-02-06]. Dostupno na: http://www. revizija.hr/izvjesca/2015/revizija/pojedinacna_izvjesca/knjiznice/gradska_knjiznica_i_citaonica_metel_ozegovic_varazdin.pdf

33 Gradska knjižnica i Knjižnica Božidara Aždije izuzete su od usklađivanja do završetka revizije. 
Izvješće o obavljenoj reviziji: Gradska knjižnica Krapina. Krapina: Državni zavod za reviziju, 2015. [citirano: 2020-02-06]. Dostupno na: http://www.revizija.hr/izvjesca/2015/revizija/pojedinacna_izvjesca/knjiznice/gradska_knjiznica_krapina.pdf

Izvješće o obavljenoj reviziji: Knjižnice grada Zagreba. Zagreb: Državni zavod za reviziju, 2015. [citirano: 2020-02-06]. Dostupno na: http://www.revizija.hr/izvjesca/2015/revizija/pojedinacna_izvjesca/knjiznice/knjiznice_grada_zagreba.pdf

Izvješće o obavljenoj reviziji: Nacionalna i sveučilišna knjižnica u Zagrebu. Zagreb: Državni zavod za reviziju, 2015. [citirano: 2020-02-06]. Dostupno na: http://www.revizija.hr/izvjesca/2015/revizija/pojedinacna_izvjesca/knjiznice/nacionalna_i_sveucilisna_knjiznica_u_zagrebu.pdf

Izvještaj o radu 2018. Zagreb: Knjižnice grada Zagreba, 2019.

Johnson, P. Fundamentals of collection development and management. Chicago: American Library Association, 2009.

Kretić Nađ, M.; M. Vehabović Štrak; R. Benić. Kakve veze ima knjižnica s računovodstvom? Beli Manastir: Gradska knjižnica, 2018.

Odluka o izražavanju financijske vrijednosti knjižničnog fonda KGZ-a od 28. 3. 2017. [interni dokument]

Odluka o isknjiženju dugotrajne i kratkotrajne nefinancijske imovine iz knjigovodstvene evidencije od 23. 1.2018. [interni dokument]

Pravilnik o proračunskom računovodstvu i računskom planu. // Narodne novine 124, 2374(2014). [citirano: 2020-02-28]. Dostupno na: https://narodne-novine.nn.hr/ clanci/sluzbeni/2014_10_124_2374.html

Pravilnik o reviziji i otpisu knjižnične građe. // Narodne novine 21, 503(2002). [citirano: 2020-02-28]. Dostupno na: https://narodne-novine.nn.hr/clanci/sluzbeni/2002_03_21_503.html

Standardi za narodne knjižnice u Republici Hrvatskoj. // Narodne novine 58, 1071(1999). [citirano: 2020-02-28]. Dostupno na: https://narodne-novine.nn.hr/clanci/sluzbeni/1999_06_58_1071.html

Tadić, K. Rad u knjižnici. Opatija: Naklada Benja, 1994.

Telenta, V. Specifičnosti knjigovodstvenog evidentiranja i popisa knjižnične građe. // Računovodstvo, revizija i financije 25, 2(2015.), str. 19-22.

Upute za usklađivanje inventarnih knjiga [interni document]

Zakon o knjižnicama i knjižničnoj djelatnosti. // Narodne novine 17, 356(2019). [citirano: 2020-02-28]. Dostupno na: https://narodne-novine.nn.hr/clanci/sluzbeni/ full/2019_02_17_356.html

Zakon o proračunu. // Narodne novine 87, 2791(2008). [citirano: 2020-02-28]. Dostupno na: https://narodne-novine.nn.hr/clanci/sluzbeni/2008_07_87_2791.html 